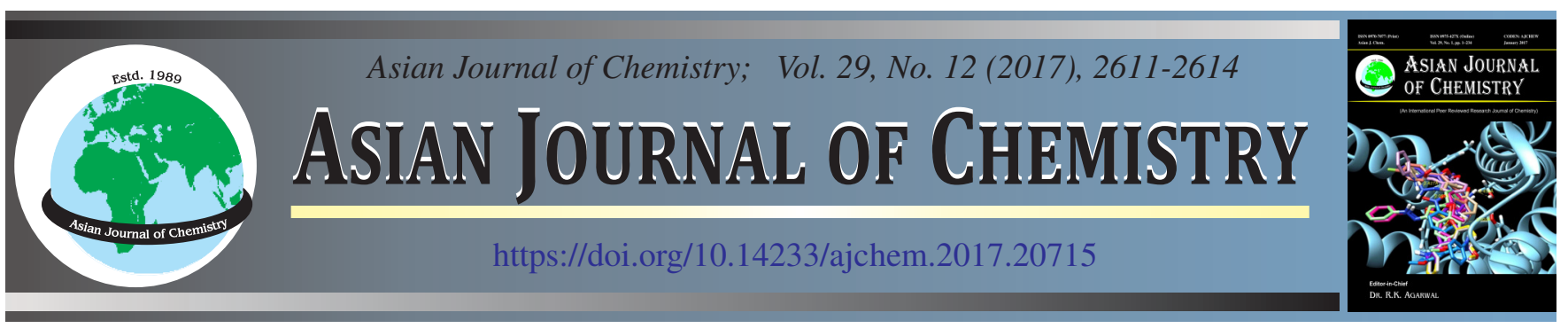

\title{
Treatment of Textile Wastewater and Sludge through Advanced Oxidation Process
}

\author{
Farah Deeba ${ }^{1}$, Naeem Abbas $^{1, *}$, Muhammad TahiR Butt ${ }^{1}$, Rauf Ahmad Khan $^{1}$ and Muhammad Muneeb Ahsan ${ }^{2}$
}

${ }^{1}$ Centre for Environmental Protection Studies, PCSIR, Laboratories Complex, Ferozepur Road Lahore-54600, Pakistan

${ }^{2}$ COMSAT Institutes of Information Technology, Lahore-54000, Pakistan

*Corresponding author: E-mail: naeemchemist@gmail.com

Received: 14 April 2017;

Accepted: 27 July 2017;

Published online: 30 October 2017;

AJC-18600

\begin{abstract}
In this study, textile wastewater has been characterized and was found to contain very high colour and total organic carbon (TOC). Fenton, Electro-Photo Fenton reagents along with combination of natural coagulants were examined for the degradation of textile dye at various dose rate and $\mathrm{pH}$. The results showed that Fenton reagent at a dose rate of $0.2 \mathrm{~mL} \mathrm{FeSO}_{4}(0.25 \mathrm{~N}), 5 \mathrm{~mL} \mathrm{H}_{2} \mathrm{O}_{2}$ and $0.5 \mathrm{~mL} \mathrm{H}_{2} \mathrm{SO}_{4}$ gave best reduction of colour $87 \%$ and TOC $56 \%$. Electrophoto Fenton was found to be effective for treatment of textile wastewater but expensive as it required energy. Sludge obtained after treatment was made metal free by acid digestion and then converted into compost. Best compost was prepared from metal free sludge in combination with dry leaves and sewerage sludge containing organic matter $91.27 \%$, cation exchange capacity $80 \mathrm{meq} / 100 \mathrm{~g}$ and $\mathrm{C} / \mathrm{N}$ ratio18: 17.
\end{abstract}

Keywords: Textile wastewater, Total organic carbon, Colour, Sludge, Compost.

\section{INTRODUCTION}

An increase in the demand of textile products proportionally increases wastewater which making it one of the main sources of water pollution in worldwide. Various type of textile dyes, auxiliary products, dispersing agents, humectant agents used in textile processing at several stages. Large amount of wastewater is produced in dyeing step in the finishing process is a major environmental problem in the textile industry [1]. Wet processing includes preparation, dyeing and finishing that produces high consumption of water chemicals and dyes. Textile wastewater contains high concentrations of total suspended solids, colour, biological and chemical oxygen demand. Commonly, dyeing and rinsing processes generate about $90-130 \mathrm{~m}^{3}$ wastewater per ton of product [2].

Wastewater produced in textile processing usually containing complex structure of different persistent pollutants, such as dyes, solvents, fats, surfactants, waxes, salts, oils, soaps and metals and a major risk for the environment and ecosystems when discharged improperly in water bodies [3].

Literature revealed that many studies were done on coagulation/flocculation process $[4,5]$ for treatment of textile wastewater. Moreover, other treatment methods like adsorption [6,7], membranes [8-10], electrocoagulation [11,12], advanced oxidation process (AOP) $[13,14]$ and biological processes $[15,16]$ have been used to remove textile dyes reported in literature.
It is significant that use of advanced oxidation process (AOP) can degrade complex organic compounds that are difficult to remove by conventional methods due to formation of highly oxidizing species such as hydroxyl radicals. Huang et al. [17] presented that for treatment of industrial effluents, advanced oxidation processes have become most promising technology near future.

Fenton and photo-Fenton reactions have been the most widely used techniques among all AOPs [18]. The production of highly oxidizing species is enhanced by applying ultraviolet light on Fenton reactants, supporting sustained chemical reactions as well as an increase in efficiency compared to other AOP-based methods for the degradation of different recalcitrant pollutants [19]. However, for improvement of wastewater treatment and to minimize cost different combinations of chemicals can be applies at once [20].

Sludge obtained from wastewater treatment plant would need proper treatment and reuse to protect environment. Usually, less toxic sludge can be converted into compost and use as biofertilizer. Composting has been known as one of the most cost effective and environmentally sound alternate for organic wastes recycling [21].

In current study, a treatment system based on advance oxidation process that includes Fenton process, Fenton reagents along with natural coagulants and Electrophoto Fenton process were applied to degrade total organic matter and removal of colour from real textile wastewater. Furthermore, the sludge obtained 
from the process was characterized and after metal removal used as substrate for compost with mixing of biomass.

\section{EXPERIMENTAL}

Sampling was made from two different textile industries of Punjab, Pakistan. Wastewater was treated by advance oxidation process. The sludge obtained from treatment was firstly made free from metal by using modified digestion methods and then converted into compost. Chemicals used in experiment viz., $\mathrm{H}_{2} \mathrm{O}_{2}(30 \%), \mathrm{HCl}, \mathrm{FeSO}_{4} \cdot 6 \mathrm{H}_{2} \mathrm{O}, \mathrm{H}_{2} \mathrm{SO}_{4},(98 \%)$ were of analytical reagent grade.

\section{Treatment of textile wastewater with advanced oxidation process}

Fenton process: To optimize process, about $300 \mathrm{~mL}$ of textile wastewater was treated with Fenton reagents by changing dose rate and at various $\mathrm{pH}$ (T1 to T3). With acidic $\mathrm{pH}$, oxidation process enhanced production of $\mathrm{OH}^{\circ}$, so treatment of dye in textile wastewater proceeded very fast. Treatment T-3 to T-6 contain same amount of wastewater with various dose rate of $\mathrm{FeSO}_{4}$ i.e., $35-140 \mathrm{mg}$ and $5 \mathrm{~mL}$ of $\mathrm{H}_{2} \mathrm{O}_{2}$ and with $0.5 \mathrm{~mL}$ $\mathrm{H}_{2} \mathrm{SO}_{4}$.

Fenton reagents with natural coagulants: Textile wastewater was treated with natural coagulants in combination with Fenton reagents. T-7 to T-11 textile wastewaterwas treated through various natural coagulants along with Fenton reagent. Natural coagulants that used in experiment include $M$. Oleifera seed (Moringia), rice husk, bagass, chick pea and wheat stalks. Whereas in treatment T-12 to T-17, $140 \mathrm{mg} \mathrm{FeSO} 4,5 \mathrm{~mL} \mathrm{H}_{2} \mathrm{O}_{2}$ $\left(30 \%\right.$ ) and $0.5 \mathrm{~mL} \mathrm{H}_{2} \mathrm{SO}_{4}$ to maintain $\mathrm{pH}>2$.

Electrophoto Fenton process: Electrolysis was done with sacrificial iron anode and carbon cathode for wastewater treatment. To aid oxidation process added $5 \mathrm{~mL}$ of $\mathrm{H}_{2} \mathrm{O}_{2}$ in treatment T-18 to T-21. Treatment was done by using UV lamp at $\mathrm{pH} 2$ and 6 and at different current density $\left(100,200 \mathrm{~mA} / \mathrm{cm}^{2}\right)$. In treatment $\mathrm{T}-18$ to 21 , electrophoto Fenton processes were applied at $300 \mathrm{~mL}$ samples of textile wastewater. The results of colour and TOC were calculated after 10-16 h.

\section{Treatment of sludge}

Isolation of metals: Characterization of textile sludge revealed that copper, iron and aluminum were found higher in amount. Acid and thermal digestion was applied to textile sludge for isolation of metals. $10 \% \mathrm{HCl}$ and $\mathrm{H}_{2} \mathrm{SO}_{4}$ were used for treatment (T-22 to T-24) of metal isolation from sludge. In thermal treatment, sample was treated in carbolite furnace at $650{ }^{\circ} \mathrm{C}$ for $3 \mathrm{~h}$.

Compost from sludge: The metal free sludge was used to prepare compost with mixing of dry leaves, bagasse and microbial source was either sewerage sludge or cow-dung. These composts were prepared after 60-90 days in treatment T-25 to $\mathrm{T}-28$. To check the feasibility of possible energy recovery metal free textile sludge was mixed with coal after grinding and passed through a sieve size of $125 \mu \mathrm{m}$.

The percentage reduction of colour, TOC and metals was calculated by using eqn. 1 :

$$
R_{p}=\frac{R_{i}-R_{f}}{R_{i}} \times 100
$$

where, $R_{p}=$ percentage reduction, $R_{i}=$ Initial reading and $R_{f}=$ Final reading.

Physico-chemical analysis: The colour of samples before and after treatment was measured by, Tintometer (LOVIBOND PFX 995). The path length of cell used for colour determination was $100 \mathrm{~mm}$. Before measurement sample were filtered to prevent turbidity. Estimation of heavy metals was carried out on Atomic Absorption Spectrophotometer (Polarized Zeeman Hitachi 2000).

Total organic carbon (TOC): Total organic carbon can be estimated by volumetric and calorimetric methods. However, the most common procedure involves reduction of $\mathrm{K}_{2} \mathrm{Cr}_{2} \mathrm{O}_{7}$ by organic compounds and subsequent determination of the unreduced dichromate by oxidation-reduction titration with ferrous sulfate. This method is referred to as Walkley-Black method [22]. In this method, weighed amount of sample is heated with $1 \mathrm{~N} \mathrm{~K}_{2} \mathrm{Cr}_{2} \mathrm{O}_{7}$ and $\mathrm{H}_{2} \mathrm{SO}_{4}$ at $150{ }^{\circ} \mathrm{C}$. Then sample is titrated with $0.5 \mathrm{~N} \mathrm{FeSO}_{4}$ in presence of Ferroin indicator. The calculation was done by eqn. 2 :

$$
\text { TOC }=\frac{\text { (meq. of } \mathrm{K}_{2} \mathrm{Cr}_{2} \mathrm{O}_{7} \text { added }- \text { meq. of } \mathrm{FeSO}_{4} \text { used) }}{\text { Weight of sample }} \times 0.336 \text { (2) }
$$

\section{RESULTS AND DISCUSSION}

Treatment of textile wastewater with advanced oxidation process: Textile wastewater is intensely colour and has a high value of TOC due to presence of organic dyes. Advanced oxidation process is effective to mineralized organic compounds present in aqueous medium. Intense colour in textile wastewater is due to organic dye used in textile industry [23]. These were used separately and in combination with different natural coagulants viz., M. Oleifera, bagasse, rice-husk, wheat stalk and chick pea at different $\mathrm{pHs}$.

In treatments T- 1 to T- 6 different dose rate of $\mathrm{FeSO}_{4} \cdot 6 \mathrm{H}_{2} \mathrm{O}$, $\mathrm{H}_{2} \mathrm{O}_{2}$ and $\mathrm{H}_{2} \mathrm{SO}_{4}$ were applied at $\mathrm{pH} 2$ and 6 . The maximum removal was found in case of T-6 that is $87 \%$ TOC and $56 \%$ colour at dose rate of $140 \mathrm{mg} \mathrm{FeSO}_{4}, 5 \mathrm{~mL} \mathrm{H}_{2} \mathrm{O}_{2}(30 \%), 0.5$ $\mathrm{H}_{2} \mathrm{SO}_{4}$ at $\mathrm{pH} 2$ for treatment of $300 \mathrm{~mL}$ of textile wastewater (Table-1). At pH 6, removal was satisfactorily in T-3 i.e., $86 \%$ TOC and $49 \%$ colour at $140 \mathrm{mg} \mathrm{FeSO}_{4}, 5 \mathrm{~mL} \mathrm{H} \mathrm{O}_{2}(30 \%)$ without addition of $\mathrm{H}_{2} \mathrm{SO}_{4}$. Ferrous sulphate helps to produce $\mathrm{OH}^{\bullet}$ free radical from $\mathrm{H}_{2} \mathrm{O}_{2}$ which oxidize organic dye very fast [24]. It was observed that at low $\mathrm{pH} 2$, oxidation reaction further became fast and effective. As Fenton process is more effective at lower $\mathrm{pH}$ [25].

Treatment T-7 to T-11 was done with Fenton reagents and natural coagulants i.e., M. Oleifera, bagasse, wheat stalks, rice husk, chick pea after grinding and passing through sieve 250 $\mu \mathrm{m}$ particle sizes. From Table-1, it was revealed that $M$. Oleifera seeds have given better results out of all natural coagulants (colour $80 \%$ and TOC $48 \%$ ). In case of bagass good results (colour $76 \%$ and TOC $46 \%$ ) was found at dose rate $140 \mathrm{mg}$ $\mathrm{FeSO}_{4} \cdot 6 \mathrm{H}_{2} \mathrm{O}, 5 \mathrm{~mL} \mathrm{H}_{2} \mathrm{O}_{2}(30 \%), 0.2 \mathrm{~g}$ bagasse at $\mathrm{pH}<5$. In treatment T-12 to T-17, textile wastewater was shaken with natural coagulants along with the addition of $0.5 \mathrm{~mL}$ sulphuric acid. It was observed that there was no further decrease in colour and TOC when we added the acid with natural coagulants.

Table-2 represents electrophoto Fenton process for treatment (T-18 to T-21) of textile wastewater. Electrolysis was done with 


\begin{tabular}{|c|c|c|c|c|c|}
\hline \multicolumn{6}{|c|}{$\begin{array}{c}\text { TABLE-1 } \\
\text { TREATMENT OF TEXTILE WASTEWATER BY FENTON REAGENTS, } \\
\text { COMBINATION OF FENTON REAGENTS AND NATURAL COAGULANTS }\end{array}$} \\
\hline $\begin{array}{l}\text { Treat- } \\
\text { ment } \\
\text { No\# }\end{array}$ & Treatment conditions & $\begin{array}{l}\text { colour (Pt- } \\
\text { Co/Hazen) }\end{array}$ & $\begin{array}{l}\text { Reduction } \\
\text { in colour } \\
(\%)\end{array}$ & $\begin{array}{c}\text { Mean } \\
\text { average } \\
\text { value of } \\
\text { TOC } \\
(\%)\end{array}$ & $\begin{array}{l}\text { TOC } \\
\text { reduc- } \\
\text { tion } \\
(\%)\end{array}$ \\
\hline $\mathrm{T}-0$ & Original Sample & 1980 & - & 6.95 & - \\
\hline \multicolumn{6}{|c|}{ Fenton reagents } \\
\hline $\mathrm{T}-1$ & $35 \mathrm{mgFeSO}_{4}+1 \mathrm{~mL} \mathrm{H}_{2} \mathrm{O}_{2}(30 \%) \mathrm{pH} 6$ & $1227.6 \pm 5.7$ & 38 & 5.28 & $24 \pm 1.7$ \\
\hline $\mathrm{T}-2$ & $70 \mathrm{mg} \mathrm{FeSO}+3 \mathrm{~mL} \mathrm{H}_{2} \mathrm{O}_{2}(30 \%) \mathrm{pH} 6$ & $594 \pm 4.9$ & 70 & 3.82 & $45 \pm 2.7$ \\
\hline $\mathrm{T}-3$ & $140 \mathrm{mg} \mathrm{FeSO}+5 \mathrm{~mL} \mathrm{H}_{2} \mathrm{O}_{2}(30 \%) \mathrm{pH} 6$ & $277.2 \pm 1.5$ & 86 & 3.54 & $49 \pm 1.9$ \\
\hline $\mathrm{T}-4$ & $35 \mathrm{mg} \mathrm{FeSO}_{4}+1 \mathrm{~mL} \mathrm{H}_{2} \mathrm{O}_{2}(30 \%)+0.5 \mathrm{~mL} \mathrm{H}_{2} \mathrm{SO}_{4}$ (Conc.) $\mathrm{pH}=2$ & $871.2 \pm 4.5$ & 56 & 4.44 & $36 \pm 1.3$ \\
\hline $\mathrm{T}-5$ & $70 \mathrm{mg} \mathrm{FeSO}+3 \mathrm{~mL} \mathrm{H}_{2} \mathrm{O}_{2}(30 \%)+0.5 \mathrm{H}_{2} \mathrm{SO}_{4}$ (Conc.) $\mathrm{pH}=2$ & $435.6 \pm 3.1$ & 78 & 3.34 & $52 \pm 3.4$ \\
\hline $\mathrm{T}-6$ & $140 \mathrm{mg} \mathrm{FeSO}+5 \mathrm{~mL} \mathrm{H}_{2} \mathrm{O}_{2}(30 \%)+0.5 \mathrm{H}_{2} \mathrm{SO}_{4}$ (Conc.) $\mathrm{pH}=2$ & $257.4 \pm 2.2$ & 87 & 3.05 & $56 \pm 3.5$ \\
\hline \multicolumn{6}{|c|}{ Fenton reagents and natural coagulants without acid } \\
\hline T-7 & $140 \mathrm{mg} \mathrm{FeSO}_{4}+5 \mathrm{~mL} \mathrm{H}_{2} \mathrm{O}_{2}(30 \%)++0.2 \mathrm{~g}$ M. oleifera, $\mathrm{pH}<5$ & $396 \pm 2.1$ & 80 & 3.61 & $48 \pm 1.2$ \\
\hline $\mathrm{T}-8$ & $140 \mathrm{mg} \mathrm{FeSO}_{4}+5 \mathrm{~mL} \mathrm{H}_{2} \mathrm{O}_{2}(30 \%)++0.2 \mathrm{~g}$ Bagasse, $\mathrm{pH}<5$ & $475.2 \pm 2.3$ & 76 & 3.75 & $46 \pm 1.4$ \\
\hline $\mathrm{T}-9$ & $140 \mathrm{mg} \mathrm{FeSO}_{4}+5 \mathrm{~mL} \mathrm{H}_{2} \mathrm{O}_{2}(30 \%)+0.2 \mathrm{~g} \mathrm{Rice} \mathrm{husk,} \mathrm{pH}<5$ & $455.4 \pm 5.3$ & 77 & 3.82 & $45 \pm 1.5$ \\
\hline $\mathrm{T}-10$ & $140 \mathrm{mg}+5 \mathrm{~mL} \mathrm{H}_{2} \mathrm{O}_{2}(30 \%)++0.2 \mathrm{~g}$ Wheat stalk, $\mathrm{pH}<5$ & $495 \pm 4.7$ & 75 & 3.89 & $44 \pm 1.2$ \\
\hline $\mathrm{T}-11$ & $140 \mathrm{mg}+5 \mathrm{~mL} \mathrm{H}_{2} \mathrm{O}_{2}(30 \%)+0.2 \mathrm{~g}$ Chick pea, $\mathrm{pH}<5$ & $495 \pm 2.3$ & 75 & 3.89 & $44 \pm 1.9$ \\
\hline \multicolumn{6}{|c|}{ Fenton reagents and natural coagulants with acid } \\
\hline $\mathrm{T}-12$ & $140 \mathrm{mg} \mathrm{FeSO}_{4}+5 \mathrm{~mL} \mathrm{H}_{2} \mathrm{O}_{2}(30 \%)+0.5 \mathrm{~mL} \mathrm{H}_{2} \mathrm{SO}_{4}(\mathrm{Conc})+.0.2 \mathrm{~g}$ M. oleifera, $\mathrm{pH}<2$ & $415.8 \pm 2.3$ & 79 & 3.68 & $47 \pm 2.3$ \\
\hline $\mathrm{T}-13$ & $140 \mathrm{mg} \mathrm{FeSO}_{4}+5 \mathrm{~mL} \mathrm{H}_{2} \mathrm{O}_{2}(30 \%)+0.5 \mathrm{~mL} \mathrm{H}_{2} \mathrm{SO}_{4}$ (Conc. $)+0.2 \mathrm{~g}$ Bagasse, $\mathrm{pH}<2$ & $475.2 \pm 2.1$ & 76 & 3.82 & $45 \pm 2.4$ \\
\hline $\mathrm{T}-14$ & $140 \mathrm{mg} \mathrm{FeSO}+5 \mathrm{~mL} \mathrm{H}_{2} \mathrm{O}_{2}(30 \%)+0.5 \mathrm{~mL} \mathrm{H}_{2} \mathrm{SO}_{4}$ (Conc. $)+0.2 \mathrm{~g}$ Rice husk, $\mathrm{pH}<2$ & $475.2 \pm 2.3$ & 76 & 3.82 & $45 \pm 1.2$ \\
\hline $\mathrm{T}-15$ & $140 \mathrm{mg}+5 \mathrm{~mL} \mathrm{H}_{2} \mathrm{O}_{2}(30 \%)+0.5 \mathrm{~mL} \mathrm{H}_{2} \mathrm{SO}_{4}$ (Conc. $)+0.2 \mathrm{~g}$ Wheat stalk, $\mathrm{pH}<2$ & $495 \pm 2.1$ & 75 & 3.82 & $45 \pm 2.8$ \\
\hline $\mathrm{T}-16$ & $140 \mathrm{mg}+5 \mathrm{~mL} \mathrm{H}_{2} \mathrm{O}_{2}(30 \%)+0.5 \mathrm{~mL} \mathrm{H}_{2} \mathrm{SO}_{4}($ Conc. $)+0.2 \mathrm{~g}$ Chick pea, $\mathrm{pH}<2$ & $495 \pm 2.3$ & 75 & 3.89 & $44 \pm 1.8$ \\
\hline $\mathrm{T}-17$ & $140 \mathrm{mg} \mathrm{FeSO}_{4}+5 \mathrm{~mL} \mathrm{H}_{2} \mathrm{O}_{2}(30 \%)+0.5 \mathrm{~mL} \mathrm{H}_{2} \mathrm{SO}_{4}$ (Conc.) $+0.2 \mathrm{~g}$ M. oleifera, $\mathrm{pH}<2$ & $396 \pm 3.9$ & 80 & 3.68 & $47 \pm 1.9$ \\
\hline
\end{tabular}

sacrificial iron net anode and carbon cathode along with UV lamp on $300 \mathrm{~mL}$ of wastewater with addition of $\mathrm{H}_{2} \mathrm{O}_{2}$. Electrolysis was also proceeding with and without UV lamp at $\mathrm{pH} 2$ and 6. It was observed that at low $\mathrm{pH}$, oxidation process not only become fast and also time saving with less production of sludge. It was observed from Table-2 that the reduction percentage of colour and TOC was slightly greater with UV lamp than in electrophoto-Fenton without UV lamp. Maximum reduction of colour and TOC (91\% and $57 \%$, respectively) were found with treatment having $200 \mathrm{~mA} / \mathrm{cm}^{2}$, UV lamp, $5 \mathrm{~mL} \mathrm{H}_{2} \mathrm{O}_{2}, \mathrm{pH}$ 2 at $10 \mathrm{~min}$ for $300 \mathrm{~mL}$ samples of wastewater. This process gave better results within 10-50 min as compared to Fenton process.

The main advantage of electrophoto Fenton process produced less amount of sludge with high TOC removal. This is due to higher production of $\mathrm{OH}^{\bullet}$ redicals resulting from the greater photon intensity supplied [26]. Electrophoto Fenton reaction is followed by equation 3 :

$$
\mathrm{Fe}(\mathrm{OH})^{2+}+\mathrm{h} v \longrightarrow \mathrm{Fe}^{2+}+\mathrm{OH}^{\bullet}
$$

Electrophoto Fenton was very effective and time saving but expensive as it needs energy [27]. From Tables 1 and 2, it was observed that $\mathrm{H}_{2} \mathrm{O}_{2}, \mathrm{FeSO}_{4}$ and natural coagulants gave less reduction of colour and TOC. However, maximum reduction in colour and TOC were observed when treatment was done with electrophoto Fenton process.

Treatment of sludge: Textile sludge contains high amount of $\mathrm{Cu}, \mathrm{Fe}$ and $\mathrm{Al}(145,331,102 \mathrm{mg} / \mathrm{kg}$ ) (Table-3). Fig. 1 shows that maximum isolation of metals was found in case of thermal digestion at $650{ }^{\circ} \mathrm{C}$. It was also observed that $10 \%$ sulphuric acid was found effective to leach out metals $\mathrm{Cu}, \mathrm{Fe}$ and $\mathrm{Al}$ at $58,61,60 \%$ respectively as compared to $\mathrm{HCl}$ (Table-3). Acid

TABLE-2

TREATMENT OF TEXTILE WASTEWATER WITH ELECTRO-PHOTO FENTON PROCESS

\begin{tabular}{|c|c|c|c|c|c|}
\hline $\begin{array}{c}\text { Treatment } \\
\text { No\# }\end{array}$ & Treatment conditions & $\begin{array}{c}\text { Mean average value } \\
\text { Pt-Co /Hazen }\end{array}$ & $\begin{array}{c}\text { Colour } \\
\text { reduction }(\%) \\
\end{array}$ & $\begin{array}{c}\text { Mean average } \\
\text { value }(\%)\end{array}$ & $\begin{array}{c}\text { TOC reduction } \\
(\%)\end{array}$ \\
\hline & Original sample & 1980 & - & 6.95 & - \\
\hline $\mathrm{T}-18$ & $100 \mathrm{~mA} / \mathrm{cm}^{2}+\mathrm{UV}+5 \mathrm{~mL} \mathrm{H} \mathrm{O}_{2}+\mathrm{pH} 6+50 \mathrm{~min}$ & $237.6 \pm 2.1$ & 88 & 3.33 & 52 \\
\hline $\mathrm{T}-19$ & $100 \mathrm{~mA} / \mathrm{cm}^{2}+\mathrm{UV}+5 \mathrm{~mL} \mathrm{H}_{2} \mathrm{O}_{2}+\mathrm{pH} 2+15 \mathrm{~min}$ & $198 \pm 1.3$ & 90 & 3.19 & 54 \\
\hline $\mathrm{T}-20$ & $200 \mathrm{~mA} / \mathrm{cm}^{2}+\mathrm{UV}+5 \mathrm{~mL} \mathrm{H} \mathrm{O}_{2}+\mathrm{pH} 6+40 \mathrm{~min}$ & $217.6 \pm 1.5$ & 89 & 3.68 & 53 \\
\hline $\mathrm{T}-21$ & $200 \mathrm{~mA} / \mathrm{cm}^{2}+\mathrm{UV}+5 \mathrm{~mL} \mathrm{H} \mathrm{O}_{2}+\mathrm{pH} 2+10 \mathrm{~min}$ & $178.2 \pm 1.2$ & 91 & 2.98 & 57 \\
\hline
\end{tabular}

TABLE-3

EXTRACTION/ISOLATION OF METALS FROM TEXTILE TREATED SLUDGE

\begin{tabular}{clcc}
\hline Treatment No\# & \multicolumn{1}{c}{ Metals in sludge } & Copper $(\%)$ & Iron $(\%)$ \\
\hline T-22 & Extracted metals $\%(10 \% \mathrm{HCl}$ acid digestion) & 56 & 59 \\
$\mathrm{~T}-23$ & Extracted metals $\%\left(10 \% \mathrm{H}_{2} \mathrm{SO}_{4}\right.$ acid digestion) & 58 & 61 \\
$\mathrm{~T}-24$ & Extracted metals $\%$ (Thermal digestion $\left.650{ }^{\circ} \mathrm{C}\right)$ & 50 & 62 \\
\hline
\end{tabular}


TABLE-4

CHARACTERIZATION OF COMPOST FOR DIFFERENT PROPORTIONS OF

SLUDGE, COW DUNG, BAGASS, SEWERAGE SLUDGE AND DRIED LEAVES

\begin{tabular}{cccccccc}
\hline Treatment No\# & Proportions & $\mathrm{N}(\%)$ & $\mathrm{P}(\%)$ & $\mathrm{K}(\%)$ & $\mathrm{OM}(\%)$ & $\mathrm{CEC}$ meq/100g & C/N \\
\hline T-25 & T + CD + B & 2.5 & 0.032 & 0.336 & 82.34 & 44 & 19.05 \\
T-26 & T + SS + B & 2.7 & 0.036 & 0.445 & 81.30 & 64 & 17.34 \\
T-27 & T + CD + L & 2.8 & 0.038 & 0.470 & 87.55 & 70 & 18.05 \\
T-28 & T + SS + L & 2.9 & 0.042 & 0.481 & 91.27 & 80 & 18.17 \\
\hline
\end{tabular}

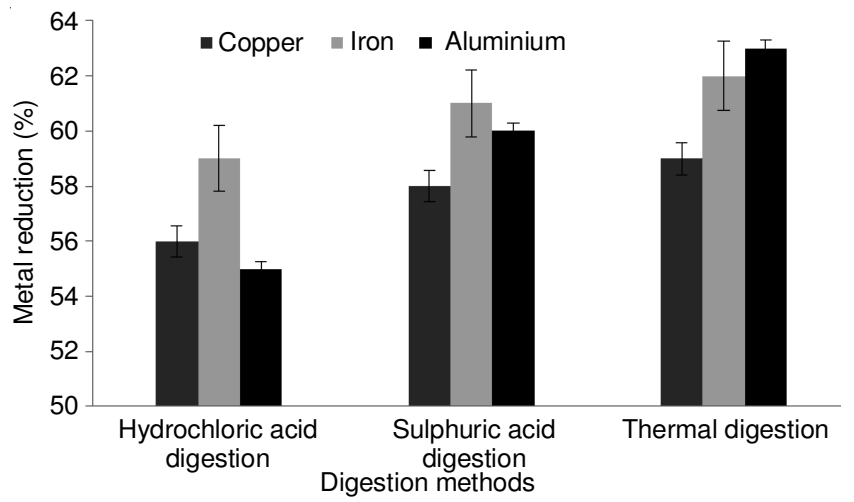

Fig. 1. Copper, iron and aluminum reduction by use of various digestion methods

leached maximum percentage of metals from sludge, further increase in acid percentage did not effecton leaching of metals and sulphuric acid gave better isolation of metals from $\mathrm{HCl}$ (Table-1). Thermal digestion was found good for isolation of metals as compared to acid but it is expensive method. The isolated metals can be utilized in electroplating or other purposes after separation.

Metal free textile sludge was subjected to prepare compost in order to adopt environmentally friendly practices. Table-4 revealed that four different types of compost that were prepared by mixing metal free textile sludge with leaves, bagass, cow dung and sewerage sludge were used for microbial load. It was observed that better compost was prepared (T-28) by dry leaves and sewerage sludge as far as composting parameters were concerned (OM $91.27 \%$, CEC $80 \mathrm{meq} / 100 \mathrm{~g}$ and $\mathrm{C} / \mathrm{N}$ ratio 18:17) as shown in Table-4.

\section{Conclusions}

- Fenton treatments, $0.2 \mathrm{~m} \mathrm{~L}(0.25 \mathrm{~N}) \mathrm{FeSO}_{4} \cdot 6 \mathrm{H}_{2} \mathrm{O}, 5 \mathrm{~mL}$ $\mathrm{H}_{2} \mathrm{O}_{2}(30 \%), 0.5 \mathrm{~mL} \mathrm{H}_{2} \mathrm{SO}_{4}$ gave best reduction of colour 87 $\%$ and TOC $56 \%$ at $\mathrm{pH} 2$ as free radical was more effective at this $\mathrm{pH}$. M. oleifera was found to be best out of five other natural coagulants to reduce colour dye intensity. These natural coagulants lower $\mathrm{pH}$ of the medium; hence treatment was effective without acid addition.

- Electrophoto-Fenton process is highly effective (colour $91 \%$ and TOC $57 \%$ reduction) and time saving but need energy. With an increase in current density time became further less for equivalent results in colour and TOC reduction.

- Thermal digestion isolates higher percentage of metals from textile sludge, but it was more expensive due to energy consumption. Among acid digestion $10 \% \mathrm{H}_{2} \mathrm{SO}_{4}$ was found more effective to leach maximum metals as compared to $\mathrm{HCl}$.

- The analysis of compost showed that dry leaves, sewage sludge and textile sludge produced better compost as compared to bagasse.

\section{REFERENCES}

1. I. Khouni, B. Marrot, P. Moulin and R. Ben Amar, Desalination, 268, 27 (2011);

https://doi.org/10.1016/j.desal.2010.09.046.

2. A.K. Verma, R.R. Dash and P. Bhunia, J. Environ. Manage., 93, 154 (2012); https://doi.org/10.1016/j.jenvman.2011.09.012.

3. N. Ali, A. Hameed and S. Ahmed, J. Hazard. Mater, 164, 322 (2009); https://doi.org/10.1016/j.jhazmat.2008.08.006.

4. S.P. Buthelezi, A.O. Olaniran and B. Pillay, Molecules, 17, 14260 (2012); https://doi.org/10.3390/molecules171214260.

5. F.Y. Qian, X.B. Sun and Y.D. Liu, Chem. Eng. J., 214, 112 (2013); https://doi.org/10.1016/j.cej.2012.09.130.

6. S.R. Syeda, S.A. Ferdousi and K.M.T. Ahmmed, J. Environ. Sci. Health A, 47, 210 (2012);

https://doi.org/10.1080/10934529.2012.640566.

7. A.A. Ahmad and B.H. Hameed, J. Hazard. Mater., 173, 487 (2010); https://doi.org/10.1016/j.jhazmat.2009.08.111.

8. E. Ellouze, N. Tahri and R.B. Amar, Desalination, 286, 16 (2012); https://doi.org/10.1016/j.desal.2011.09.025.

9. X.J. Wang, Q.K. Xu and L.Q. Qi, Adv. Mater. Res., 441, 578 (2012); https://doi.org/10.4028/www.scientific.net/AMR.441.578.

10. A. Babuponnusami and K. Muthukumar, Chem. Eng. J., 183, 1 (2012); https://doi.org/10.1016/j.cej.2011.12.010.

11. V. Khandegar and A.K. Saroha, J. Environ. Manage., 128, 949 (2013); https://doi.org/10.1016/j.jenvman.2013.06.043.

12. C. Phalakornkule, S. Polgumhang, W. Tongdaung, B. Karakat and T. Nuyut, J. Environ. Manage., 91, 918 (2010); https://doi.org/10.1016/j.jenvman.2009.11.008.

13. A.N. Modenes, F.R. Espinoza-Quinones, D.R. Manenti, F.H. Borba, S.M. Palacio and A. Colombo, J. Environ. Manage., 104, 1 (2012); https://doi.org/10.1016/j.jenvman.2012.03.032.

14. S.M. Palacio, F.R. Espinoza-Quiñones, A.N. Modenes, D.R. Manenti, C.C. Oliveira and J.C. Garcia, Water Sci. Technol., 65, 1392 (2012); https://doi.org/10.2166/wst.2012.015.

15. Z.M. Fu, Y.G. Zhang and X.J. Wang, Adv. Mater. Res., 518, 2961 (2012); https://doi.org/10.4028/www.scientific.net/AMR.518-523.2961.

16. M.S. Alvarez, F. Moscoso, A. Rodriguez, M.A. Sanromán and F.J. Deive, Bioresour. Technol., 146, 689 (2013); https://doi.org/10.1016/j.biortech.2013.07.137.

17. C.P. Huang, C. Dong and Z. Tang, Waste Manag., 13, 361 (1993); https://doi.org/10.1016/0956-053X(93)90070-D.

18. I. Oller, S. Malato and J.A. Sánchez-Pérez, Sci. Total Environ., 409, 4141 (2011); https://doi.org/10.1016/j.scitotenv.2010.08.061.

19. S. Malato, P. Fernández-Ibáñez, M.I. Maldonado, J. Blanco and W. Gernjak, Catal. Today, 147, 1 (2009); https://doi.org/10.1016/j.cattod.2009.06.018.

20. K. Sarayu and S. Sandhya, Appl. Biochem. Biotechnol., 167, 645 (2012); https://doi.org/10.1007/s12010-012-9716-6.

21. R.P. Singh and M. Agrawal, Ecotoxicol. Environ. Saf., 73, 632 (2010); https://doi.org/10.1016/j.ecoenv.2010.01.020.

22. A. Walkley, Soil Sci., 63, 251 (1947); https://doi.org/10.1097/00010694-194704000-00001.

23. A.R. Tehrani-Bagha, N.M. Mahmoodi and F.M. Menger, Desalination, 260, 34 (2010); https://doi.org/10.1016/j.desal.2010.05.004.

24. F. Haber and J. Weiss, Proc. Royal. Soc. Ser., 147, 332 (1934); https://doi.org/10.1098/rspa.1934.0221.

25. S. Hashemian, M. Tabatabaee and M. Gafari, J. Chem., Article ID 509097 (2012); https://doi.org/10.1155/2013/509097.

26. A. Altin, Sep. Purif. Technol., 61, 391 (2008); https://doi.org/10.1016/j.seppur.2007.12.004.

27. R. Priambodo, Y.J. Shih, Y.J. Huang and Y.H. Huang, Sustain. Environ. Res., 21, 389 (2011). 